\title{
Understanding the Impact of Adopting Intellectual Capital Components on Achieving the Competitive Advantage (Case of Jordanian Insurance Companies)
}

\author{
Ade Al-Nimri Yaseen M. Altarawaneh* \\ School of Business, The University of Jordan, Amman 11942, Jordan
}

\begin{abstract}
In this paper we examine the level and determinants of competitive advantage in Jordanian insurance companies because of its importance in giving a unique position to companies in the market to be superior to its competitors. However, this study concludes that the relationship between intellectual capitals measured by "Structural Capital" has a significant positive influence on competitive advantage. While the other variables "Human capital and structural capital" have no statistical significant impact on competitive advantage. Despite the importance of this study, it holds some limitations. First, the current research may show other relationships among variable at different points of testing. Second, this research was conducted in small country (Jordan) that is considered to be a developing country. The results may not generalize to other developed countries. Third, despite the fact that the current study has sufficient sample size, the appropriate sampling of the research impedes the generalization of findings.
\end{abstract}

Keywords: Intellectual Capital, Human Capital, Structural Capital, Relational Capital, Competitive Advantage, Jordanian Insurance Sector.

DOI: $10.7176 / \mathrm{EJBM} / 12-23-08$

Publication date:August $31^{\text {st }} 2020$

\section{Introduction}

Extreme competitiveness of contemporary societies stands out as a dominant feature. In these societies, leading organizations aspire to become more distinctive than other active organizations in the same field. To achieve this, organizations invest in the individuals' mental and intellectual strength, and invest in the added values that make clients feel recognizably different from the way other organizations treat them. In modern economies, intellectual capital occupies a prominent position in business because it can protect the competitive advantages and create added value to companies. This is a good reason to lead companies to increase their investments in intellectual capital. After the material resources were the actual wealth of the organizations, the investment of intellectual capital became a condition for achieving the competitive advantage to any organization in any sector, whatever its size is. Modern strategies in the managing and operating organizations became based on none material capital as an important rule of thumb to be built upon. Numbers of reasons make Intellectual capital an important element of any organization; among these reasons the enhancements the Intellectual capital has on human potentials and capacities; as well as the encouragements that lead people to pay attention to their prospect customers. These reasons allow nonmaterial assets to gain competitive advantages (Yaseen, et al., 2016). To achieve the objective of intellectual capital in promoting and stimulating competitive advantage, it is necessary to prepare for a range of different programs within the Organization's work requirements on one side, and on the organizations' Strategic Framework on the other side. Intellectual capital is obtaining increasing interest from investors and external parties as a key feature of the company's competitive position and strength among other companies. Investors look at the annual reports to judge the company's performance; these annual reports disclose intellectual capital that characterize the status of the company and its competitive position among other companies.

The study emphasizes the importance of intellectual capital, which plays an important role in creating added value to the company, and maintaining competitive advantage through its contribution to the identification and development of the flow of individuals' organizational and cognitive capabilities; These capabilities enable the company to develop new products, and thus increase the company's market value , maximize its strengths, and achieve a competitive advantage that makes it unique to other companies.

It became an important matter to take intellectual capital seriously and consider it as an effective tool for determining the economic value of business organizations, and measuring nonmaterial assets, and therefore evaluating the economic performance to achieve the competitive advantages. Intellectual capital provides a valid and true database for information users, prospective investors, and current investors through information on the efficiency of the capital markets. A number of researchers indicate that the occurrence of revenue losses at various levels is mostly due to the neglect of intellectual capital, plus failure to understand the process of creating value. Based on the above, there is a serious need to demonstrate the impact of intellectual capital on the achievement of competitive advantage, so this study emerged.

Relative to the above, the main aim of this study is to examine the impact of intellectual capital components 
(Human Capital, Structural Capital and Relational Capital) on the competitive advantage in Jordanian insurance companies.

\section{Study Model}

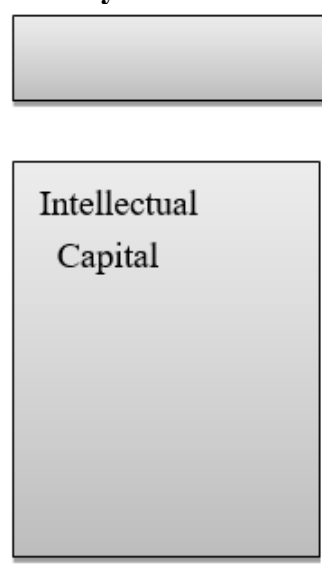

Independent Variable

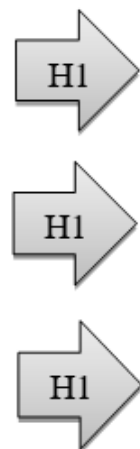

\section{Human Capital}

Structural Capital

Relational Capital

Figure (1) Model of the Study
Dependent Variable

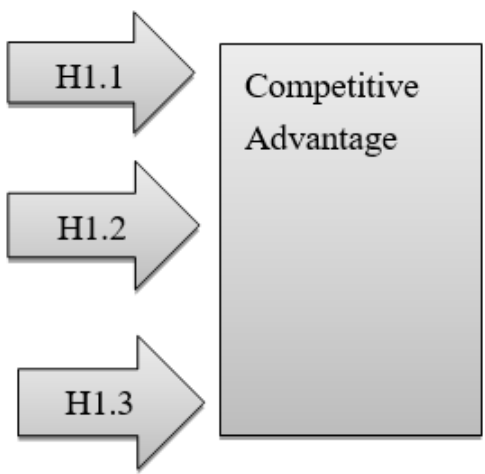

Source: This model has been prepared by the researcher, based on (Yaseen, et al., 2016)

\section{Study Hypotheses}

Ho.1: There is no statistical significant impact of intellectual capital on the achievement of competitive advantage in the Jordanian Insurance Companies at level $(\alpha \leq 0.05)$.

This gives rise to a number of sub-hypotheses:

Ho.1.1: There is no statistical significant impact of Human Capital on the achievement of competitive advantage in the Jordanian Insurance Companies at level $(\alpha \leq 0.05)$.

Ho.1.2: There is no statistical significant impact of Structural Capital on the achievement of competitive advantage in the Jordanian Insurance Companies at level $(\alpha \leq 0.05)$.

Ho.1.3: There is no statistical significant impact of Relational Capital on the achievement of competitive advantage in the Jordanian Insurance Companies at level $(\alpha \leq 0.05)$.

\section{Literature Review}

The development of network and information technology and the expansion of competition within the knowledge economy, led to increased interest in intellectual capital; thus, modern and Jordanian business organizations should adopt and innovate modern ways and means to insure sustainability, survival and competitiveness in this changing business environment (Ashour and Quaidri, 2012).Because intellectual capital became one of the most prominent elements that indicate the extent of any company's competitiveness and strength when compared with other companies, users of financial reports demand more disclosure of intellectual capital.

(Chauvel \& Despres, 2004) define intellectual capital as an indicative to the intellectual property of the enterprise through which the enterprise is granted legal protection; Intellectual capital is based on the standard that human interaction becomes continuous in a precise and natural way when knowledge is accomplished concretely and consistently. The intellectual capital was defined by (Ashour and Qweidari, 2011) as an economic value for two categories of intangible assets, human capital and structural capital. (Mention, 2012) defined intellectual capital as the organization's knowledge skills that allow the increase of competitive level to gain globalism by satisfying clients demands and by using opportunities offered by technology. (Al-Mafriji and Saleh, 2003) believe that intellectual capital is a part of the human capital of the organization, represented by unique employees who possess a number of organizational and cognitive abilities that allow them to develop and generate ideas that enable the organization to acquire the right opportunities and highlight their strengths to expand their market value.

(Heizer \& Render, 1999) indicate that the competitive advantage is concerned with providing the individual advantage to a company to steer it to the lead. Competitive advantages add the element of excellence and exclusivity to the company over other competitors in the same field. According to Stewart the intellectual capital components are: 1. Human Capital: The value provided by the organizations employees, it includes the capability of practical application, competencies, abilities and expertise. (Stewart, 1995) 2. Relational Capital: The value obtained from meeting the wishes of suppliers, customers, and all parties that deal with the company. It includes the following main components: supplier relations, trade names, licenses, concessions, customer relations and trademarks; and it clarifies the idea of separating customers' capital from structural and human capital, in addition to the extent of intellectual capital's significance (Stewart,1995)3. Structural Capital: The Company's ability to 
deploy, transfer and employ existing skills, competencies, and knowledge to real-world workers and production centers. An appropriate and specific organizational structure of responsibilities and competencies should be available and characterized by competence in the application of knowledge. (Stewart, 1995).

(Macmillan and Tampo, 2000) argue that companies seeking excellence in their environment acquire competitive advantage and maintain it as a possible tool to beat competitors. Competitive advantage exists when a company is able to complete its various activities more effectively and at a lower cost by employing resources more competently than competitors; or by utilizing its expertise and proficiency in completing its activities in a way that maximizes customer value relative to competitors (Suleiman, 2004). Economist emphasized that competitive advantage is a distinguishing feature of the company's differentiation from competitors. It distinguishes the company by the factors and resources that give it internal mobility. It also builds a strong position through Providing services and commodities of unique value to targeted customers.

\section{The Data and Methodology}

Empirical data collected from 85 managers and heads sections out of about 100 managers working at 26 insurance companies in Jordan. The questionnaire was designed and developed in contrast with hypotheses and research model.

\subsection{The Variables}

Independent variables (IC): Through literature review, the researchers have identified three important independent variables of IC that contribute to JICs'. (Human Capital, Structural Capital and Relational Capital). Each was tested by a section and multiple questions. Dependent variable of the study is related to JICs' competitive advantage. All variables were measured by taking into consideration the gender (males/ females) and the education level of managers and sections heads at JIC.

\subsection{Methodology}

In order to evaluate the determinants of competitive advantage, we perform logit estimations and use the following equation:

$$
\mathrm{X}_{\mathrm{i}}=\alpha+\beta * \text { Gender }_{\mathrm{i}}+\sigma * \text { Education }_{\mathrm{i}}+\Phi^{*} \text { Intellectual Capital }_{\mathrm{i}}+\varepsilon_{\mathrm{i}}
$$

Where $\mathrm{X}$ is the competitive advantage variable and $\mathrm{i}$ represents one given individual. The individual characteristics are the explanatory variables. Gender is a dummy variable equal to zero if the individual is a woman (Female) and one else. Age is represented as a dummy variable equal to 0 if the age between (18-25) and 1 if the age equal 26 or more (Age). Regarding to education, we use dummy variables equal to 1 if individual is holding B.A degree and zero else wise. In addition to use three dummy variables (Relational Capital, Human Capital and Structural Capital) as measurements for Intellectual Capital. Table 1 reports the descriptive statistics for the individual characteristics.

Table 1. Descriptive statistics for the main variables in the estimations

\begin{tabular}{|c|c|c|c|c|}
\hline Variables & Definition & Obs. & Mean & St. dev. \\
\hline Gender & $=0$ if female, $=1$ Male & 85 & 0.51 & 0.50 \\
\hline Age & $\begin{array}{l}=0 \text { if age from }(18-25),=1 \text { if age } \\
\text { equal } 26 \text { or more }\end{array}$ & 85 & 0.55 & 0.50 \\
\hline Education & $\begin{array}{l}=1 \text { if holdingBA degree, }=\text { Ofor } \\
\text { holding MA and PHD degree }\end{array}$ & 85 & 0.80 & 0.40 \\
\hline Competitive Advantage & $\begin{array}{l}=1 \text { if there is any possibility to } \\
\text { subscribe with the firm quintile, }= \\
\text { Ootherwise }\end{array}$ & 85 & 0.46 & 0.50 \\
\hline Relational Capital & $\begin{array}{l}=1 \text { if the firm works to satisfy its } \\
\text { customers, }=0 \text { otherwise }\end{array}$ & 85 & 0.58 & 0.50 \\
\hline Human Capital & $\begin{array}{l}=1 \text { if the firm is making great effort to } \\
\text { keep the knowledgeable individuals, } \\
=0 \text { otherwise }\end{array}$ & 85 & 0.88 & 0.32 \\
\hline Structural Capital & $\begin{array}{l}=1 \text { if the firm employees have the } \\
\text { freedom to make decisions that relate } \\
\text { to their daily job, }=0 \text { otherwise }\end{array}$ & 85 & 0.06 & 0.24 \\
\hline
\end{tabular}

Data source: Authors' calculations.

\section{The Statistical Treatments, Estimation and Findings}

This section is devoted to the presentation of estimation and main empirical findings. We first describe the statistical treatment and then present the results for the determinants of the main competitive advantage indicator. We notice from Table 2 that the values of the VIF for all variables are less than 10 and these variables are not 
suffering from inflation in the variance of their parameters. This means that there is no multi-collinearity between these explanatory variables.

Table 2. Variance Inflation Factors (VIF)

\begin{tabular}{lc}
\hline Variables & VIF \\
\hline Gender & 1.288 \\
Education & 1.233 \\
Human Capital & 1.158 \\
Structural Capital & 1.030 \\
Relational Capital & 1.174 \\
\hline
\end{tabular}

VIF: variance inflation factor is the ratio of variance in a model with multiple terms, divided by the variance of a model with one term alone It quantifies the severity of multi-collinearity in an ordinary least squares regression analysis.

Table 3. Determinants of Competitive advantage

\begin{tabular}{lcc}
\hline Variables & Competitive advantage & $\operatorname{Exp}(\mathrm{B})$ \\
\hline Gender & -0.74 & 0.48 \\
Education & 0.61 & 1.85 \\
Human Capital & 0.25 & 1.28 \\
Structural Capital & $1.98^{*}$ & 7.22 \\
Relational Capital & 0.52 & 1.69
\end{tabular}

\begin{tabular}{lc}
\hline Pseudo $\mathrm{R}^{2}$ & 0.12 \\
Log likelihood & 109.180 \\
\hline$* * *$ Denotes significance at the $1 \%$ level. ** Denotes significance at the $5 \%$ level. $*$ Denotes significance at the \\
$10 \%$ level.
\end{tabular}

Data source: Authors' calculations.

From these test result, structural capital is the only explanatory variable which has a significance value. This would mean that structural capital has significant positive influence on competitive advantage. The increase in structural capital will enhance the competitive advantage. This is because of structural capital's importance to the continuity of an organization, a good structural capital will provide convenience and comfort to its working individuals. That comfort and convenience in turn will increase productivity of the individuals and would make their working college's competitive advantage.

This result harmonizes with the research done by Taie (2014) and Sadaliaet al. (2018) that revealed significant positive influence of structural capital on competitive advantage. Which could be explained as an individual's (employee) freedom to make decisions related to their daily job, their daily job improves, so will they also have competitive performance to compete with other individuals that will improve the organization's competitive advantage. Based on coefficient determination test, it has been revealed that adjusted $\mathrm{r}$ square value $(0.12)$. This translates as intellectual capital is capable of influencing competitive advantage as much as $12.0 \%$. The rest, $(88.0 \%)$ are influence by other factors that is not covered in this research. Overall, these findings raise further questions. We wonder if individuals' characteristics and the role of leadership also determine the competitive performance.

\section{Summary and Conclusion}

In this paper we examine the level and determinants of competitive advantage in insurance sector in Jordan because of its importance in giving a unique position to firms in the market to be superior to its competitors. However, this study concludes that the relationship between intellectual capital measured by "Structural Capital" has a significant positive influence on competitive advantage. Despite the importance of this research, it holds some limitations. First, the current research may show other relationships among variable at different points of testing. Second, this research was conducted in small country (Jordan) that is considered to be a developing country. The results may not generalize to other developed countries. Third, despite the fact that the current research has sufficient sample size, the appropriate sampling of the research impedes the generalization of findings. Due to the limitations in the current research, some future research directions are suggested to improve the range of the sample to achieve a more accurate result. It is also better to add in more variables that influences competitive advantage.

\section{References}

Abazeed, R. (2017), “The Impact of Intellectual Capital Dimensions on Organizational Performance of Public Hospitals in Jordan", Global Journals Inc. (USA), Volume 17 Issue 5 Version.

Altarawneh, I. (2017), "Effect of Intellectual Capital on Competitive Advantage in the Jordanian Pharmaceutical 
Companies", European Journal of Business and Management, Vol.9, No.5, 2017.

Awad, M.A. and Ghaziri, H.M. (2004), “Knowledge Management". Upper Saddle River, New Jersey: Pearson Education, Prentice Hall.

Černe, Etinger, (2016), "IT as a part of intellectual capital and its impact on the performance of business entities", Croatian Operational Research Review CRORR 7(2016), 389-408.

Chauvel, D., Despres, C. (2004), "Organizational logic in the new age of business: The case example of Knowledge Management at Valtech", International Journal of Technology Management, Vol. 27, No. (6/7), PP. 627-611.

Guthrie, J. and Petty, R. (2000), "Intellectual Capital: Australian Annual Reporting Practices", Journal of Intellectual Capital, Vol.1, No. 3, PP. 251-241.

Guthrie, J. and Petty, R. (2004), "Using content analysis as a research method to inquire into intellectual capital reporting", Journal of intellectual capital, Vol. 5, No. 2, PP. 293-282

Hamadeen, R. and Suwaidan, M. (2014), “Content and Determinants of Intellectual Capital Disclosure: Evidence from Annual Reports of the Jordanian Industrial Public Listed Companies ”, International Journal of Business and Social Science, Vol. 5, No. 8, PP. 174-168.

Heizer, J., and Render, B., (1999), "Principles of Operations Management", $3{ }^{\text {rd }}$ ed, Prentice Hall, U.S.A.

Isaac, Santeli, Akyuz, (2017), "Intellectual Capital as a Competitive Advantage in Pan African Nigeria Limited, Abuja”, Nile Journal of Business and NileJBE Economics (2017) 7: 52-64.

Macmillan, Hugh, and Tampoe, Mahen. (2000), "Strategic Management: Process, Content, and Implementation", Oxford University Press.

Mention, L. (2012), "Intellectual Capital, Innovation and Performance: a Systematic Review of the Literature", Business and Economics Research, Vol.2, No.1, PP. 37-1

Sadalia, I., Irawati, N., \& Syafitri, I. (2018), "The Influence of Intellectual Capital on Competitive Advantage on Universities in Medan City. In 1st Economics and Business International Conference 2017 (EBIC 2017). Atlantis Press.

Sadalia, Nisrul, (2017), "The Influence of Intellectual Capital on Competitive Advantage on Universities in Medan City", Advances in Economics, Business and Management Research (AEBMR), volume 46, 1st Economics and Business International Conference 2017.

Sharabati, Nour, Shamari, (2013), "The Impact of Intellectual Capital on Jordanian Telecommunication Companies' Business Performance”, American Academic \& Scholarly Research Journal Vol. 5, No. 3.

Stewart, T. (1995), "Trying to grasp the intangible”, Fortune Magazine, PP. 157-61.

Stewart, T. A., (1998), "Intellectual Capital, the New Wealth of Organization", Crown Business, New York.

Taie, Eman Salman. (2014), "The effect of intellectual capital management on organizational competitive advantage in Egyptian hospitals", International Journal of Business and Social Science 5(2): 160-167.

Yaseen, Dajani, Hasan, (2016)," The impact of intellectual capital on the competitive advantage: Applied study in Jordanian telecommunication companies", Computers in Human Behavior 62 (2016) 168e175.

Arabic References:

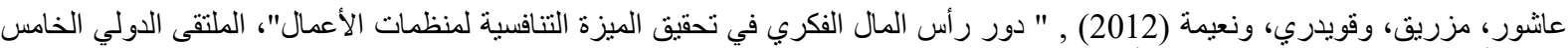

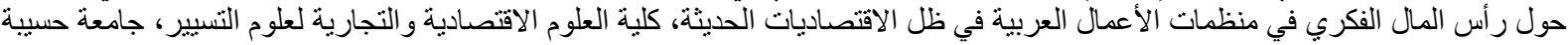
بن بو علي شلف، الجز ائر. المفرجي، عادل حرحوش، ولجزئرة وصالح، أحمد علي (2003) ," رأس المال الفكري: طرق قياسية وأساليب المحافظة عليه"، القاهرة : المنظمة العربية للتنمية الإدارية .

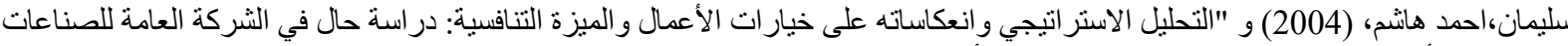

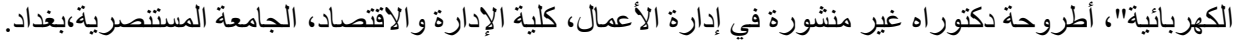

